\title{
Ruang Adat di Kampung Dukuh Dalam sebagai Bentuk Kehidupan Spiritual
}

\author{
Nani Sriwardani', Reiza D. Dienaputra, Susi Machdalena, N. Kartika \\ Program Studi Sastra, Fakultas Ilmu Budaya, Universitas Padjajaran \\ Jl. Raya Bandung Sumedang No.KM 21, Hegarmanah, \\ Kec. Jatinangor, Kabupaten Sumedang, Jawa Barat 45363 \\ Insriwardani@ymail.com
}

\begin{abstract}
Masyarakat Adat Sunda tersebar di daerah di Jawa Barat, beberapa kampung bersifat tertutup dengan mempertahankan adat istiadat kebiasaan secara turun termurun dan sebagian juga ada yang mengalami penyesuain pada nilainilai kebudayaannya. Kampung Dukuh yang terletak di Desa Cijambe, Kecamatan Cikelet, Kabupaten Garut, merupakan salah satu kampung yang memiliki keduanya. Kampung tersebut memberi batas antara "dalam" dan "luar". Pemisahan "dalam" dan "luar" ini memiliki perbedaan dalam menciptakan kesakralan ruang dan kondisi manusia yang ada di lingkungan tersebut. Penelitian ini bertujuan memberikan gambaran nilai kehidupan spiritual yang hadir melalui batas ruang lingkup suatu kampung adat. Metode yang digunakan adalah dengan pendekatan deskriptif kualitatif, dengan mengutamakan berbagai data literatur serta survei dilapangan. Hasilnya ditemukan bahwa terdapat batas wilayah atau ruang yang membatasi antara Dukuh Dalam dan Dukuh Luar. Kampung Dukuh mengedepankan akhlaq dalam sistem kehidupannya dan di Kampung Dukuh Dalam aturan tawadhu, sederhana, dan harmonis dijalankan sepernuhnya sampai kepada gaya hidup dan lingkungannya. Pegangan hidup masyarakat Kampung Dukuh Dalam berpedoman pada ajaran agama Islam yang berlandaskan Al Quran dan Hadist. Hasil dan kajian ini diharapkan dapat menjadi wawasan pengetahuan perihal Kampung Dukuh Dalam dan wilayah serta ruang yang menaunginya.
\end{abstract}

Kata kunci: ruang adat; kampung dukuh dalam, kehidupan spiritual.

\section{Traditional space in Kampung Dukuh Dalam as a Spiritual Life}

The Sundanese Indigenous People are scattered in areas in West Java, some villages are closed by maintaining their traditional customs from generation to generation, and some also experience adjustments to their cultural values. Kampung Dukuh, which is located in Cijambe Village, Cikelet District, Garut Regency, is one of the villages that has both. The village defines the boundaries between "inside" and "outside". The separation of "inside" and "outside" has a difference in creating the sanctity of space and the human condition in the environment. This study aims to provide an overview of the value of spiritual life that is present through the scope of a traditional village. The method used is a qualitative descriptive approach, by prioritizing various literature data and field surveys. The result was found that there was an area or space boundary between Dukuh Dalam and Dukuh Luar. Kampung Dukuh puts forward morality in its life system and in Kampung Dukuh Dalam the rules of tawadhu, simple and harmonious practices are fully implemented down to their lifestyle and environment. The life handle of Kampung Dukuh Dalam is guided by the teachings of Islam based on the Al-Quran and Hadith. The results and this study are expected to provide insight into knowledge about Kampung Dukuh Dalam and the area and space it houses.

Key words: customary space; kampung dukuh dalam, spiritual life. 


\section{PENDAHULUAN}

Masyarakat di Kampung Adat Sunda saat ini tersebar di beberapa daerah Jawa Barat, seperti Kampung Naga di Tasikmalaya, Kampung Kuta di Ciamis, Kampung Ciptagelar di Sukabumi, Kampung Urug di Bogor, Kampung Pulo di Garut, Kampung Dukuh di Cikelet Garut dan kampung adat lainnya. Masyarakat di kampung-kampung adat tersebut umumnya masih mempertahankan berbagai kebiasaan, pola, aturan, mentaati pantangan/larangan, menghormati kuncen, dan menjalankan nilai-nilai budaya lainnya melalui berbagai ritual adat. Beberapa wilayahnya masih memiliki pola perkampungan dengan rumah-rumah tradisional, namun ada juga beberapa kampung adat hanya menyisakan satu atau beberapa rumah adat. Kampung-kampung Sunda memiliki ruang lingkup tersendiri dalam menciptakan kehidupan bermasyarakat. Masyarakat Sunda sangat menghormati alam, hal ini terlihat dengan keberadaan kampung yang dekat dengan hutan. Umumnya kampung-kampung Sunda memiliki hutan keramat sebagai bagian dari wilayahnya. Hutan dan alam inilah yang menjadi tempat mereka menggantungkan hidupnya, yaitu sebagai mata pencarian dan sumber kehidupan seperti air, udara, dan sebagainya. Bagi masyarakat Sunda alam adalah anugerah dan harus dicintai karena hidup tergantung pada kemurahan alam (Sumardjo, 2003:40-41).

Kedekatan masyarakat Sunda dengan alam juga beriringan dengan keterbukaannya pada dunia luar. Menurut Rosidi (1984:133), sejarah menunjukkan bahwa masyarakat Sunda merupakan masyarakat yang terbuka dan mudah menerima serta menyerap pengaruh luar sehingga menjadi miliknya sendiri. Perubahan yang berada di Kampung Adat ini tidak semerta-merta mengubah keseluruhan pola pikir atau kepercayaan masyarakatnya. Tingkah laku, perbuatan, kebiasaan di beberapa wilayah kampung tidak mengalami perubahan walaupun mereka terbuka dan menerima kedatangan dunia luar. Menurut Sumardjo (2003:297), bahwa perubahan juga menunjukkan adanya pola yang tetap dan tidak berubah yang biasanya bersumber dari tata nilai awal. Inilah yang menjadikan beberapa kampung adat Sunda masih melaksanakan beberapa ritual adat, aturan dan mempercayai serta mematuhi larangan-larangan adat secara turun temurun walaupun pengaruh dan ketentuan baru juga masuk di wilayah kampung mereka.

Salah satu kampung adat yang terbuka dan menerima kedatangan dunia luar adalah Kampung Adat Dukuh. Kampung Dukuh berada di Desa Cijambe, Kecamatan Cikelet, Kabupaten Garut, Provinsi Jawa Barat. Ia merupakan salah satu kampung adat Sunda dari beberapa kampung adat yang ada di Jawa Barat. Kampung Dukuh terbagi kepada Dukuh Dalam dan Dukuh Luar. Dukuh Dalam dan Dukuh Luar hidup berdampingan namun dengan batas ruang yang berbeda. Batasan tersebut tidak menjadikan Dukuh Dalam menutup diri dari Dukuh Luar maupun masyarakat di luar wilayah Kampung Dukuh. Tata letak wilayah Kampung Dukuh yang satu namun memiliki "batas" menjadikan keduanya memiliki perbedaan ruang. Perbedaan ruang secara fisik maupun rasa antara "Dalam" dan "Luar" ini menjadi latar belakang penelitian ini. Ruang Adat di Dukuh Dalam memiliki kekuatan spiritual melalui aturan-aturan, pola perilaku, kebiasaan yang diterapkan masyarakatnya. Nilai-nilai kepercayaan dijalankan dan diamalkan dengan taat. Agama Islam menjadi kepercayaan yang dianut oleh masyarakat Kampung Dukuh, baik “dalam" maupun "luar". Dukuh Dalam yang taat aturan Islam dan mengutamakan ilmu akhlak memberikan aturan-aturan kepada masyarakatnya. Batas dan aturan menjadi ukuran saat penduduk tersebut yakin dan mau menjalankan aturan yang diterapkan di Dukuh Dalam. Batas Dukuh Dalam dan Luar ini jugalah yang membedakan bentuk rumah diantara keduanya. Rumah di Dukuh Dalam memiliki bentuk dengan aturan tertentu dan tanpa listrik, sedangkan Dukuh Luar bangunan diperbolehkan dengan bahan dan bentuk yang berbeda dari Dukuh Dalam.

Tujuan penelitian ini mengungkap ruang adat yang terbentuk dari Dukuh Dalam. Ruang adat yang menciptakan bentuk dan konsep kehidupan spiritual dari Kampung Adat Dukuh Dalam. Kampung Adat Dukuh Dalam selalu menerima kedatangan masyarakat luar kampung untuk ikut serta beribadah di wilayah Kampung Dukuh Dalam. Akses menuju Kampung Dukuh yang tidaklah mudah, namun tetap menjadi daya tarik masyarakat untuk ikut serta merasakan beribadah bersama masyarakat Kampung Dukuh Dalam. Kegiatan sholawat setiap Jumat malam, dan ziarah makam keesokan harinya merupakan kegiatan yang dilakukan setiap minggunya dan dihadiri oleh masyarakat Dukuh Dalam maupun Luar serta pendatang dari berbagai daerah di luar Kampung Dukuh. Kegiatan tersebut bagi Kampung Dukuh tidaklah wajib, namun bagi Dukuh Dalam kegiatan tersebut menjadi kegiatan yang tidak dilewatkan untuk dikerjakan. Situasi pandemik di tahun 2020 ini, nyatanya tidak menyurutkan antusiasme masyarakat Dukuh dan warga luar Dukuh untuk datang dan ikut serta mengikuti kegiatan ibadah tersebut.

Menurut masyarakat Sunda yang kebanyakan beragama Islam, bahwa agama haruslah menjadi pegangan atau pedoman dalam hidup bermasyarakat dan untuk diakhirat. Islam sebagai pedoman diamalkan dan dilaksanakan dalam kehidupan sehari-hari, tidak hanya yang wajib namun juga yang sunah (Suhamihardja, 1984a: 280). Begitu juga dengan Kampung Dukuh, masyarakatnya menganut agama Islam dengan $\mathrm{Al}$ quran dan Hadits menjadi pegangan dan pedoman dalam beribadah dan bermasyarakat. Tata letak masjid dan madrasah diletakkan sejajar dengan bangunan Bumi Adat di Kampung Dukuh Dalam yang berada paling atas dari bangunan perumahan lainnya.

Makna Ruang Adat dalam pembahasan ini mengacu pada pengertian dan konsep masyarakat Sunda. Ruang dalam bahasa Baduy memiliki arti yang hampir sama namun 
akan berbeda arti tergantung pada penempatan kalimat dan penunjukan batas yang dimaksud atau ungkapkan. Kata Ruang (ruang, rohang dan roang) memiliki pernyataan yang hampir sama, yaitu tentang tempat, dan salah satunya juga dapat diartikan sebagai keadaan yang mempunyai batas-batas tertentu baik konkrit maupun abstrak. Ruang permukiman berkaitan hubungan ruang dengan keletakannya yang mengacu pada susunan, tempat-tempat atau tempat terdapatnya sesuatu contohnya tempat tinggal, tempat mandi dan sebagainya (Permana, 2006:50-51). Ruang juga dapat diartikan sebagai wadah. Konsep wadah dan isi (eusi) ini sebagai penjabaran filosofi cara berfikir masyarakat Sunda Lama dan masih tampak dalam pergaulan. Konsep ini menyebutkan bahwa wadah adalah ruang, baik individual maupun komunal, isi yang dimaksud adalah kualitas, mental dan spiritual. Wadah tidak harus berisi individu atau kumpulan individu, tetapi juga benda-benda. (Sumardjo, 2003:255-256). Mengacu pada ruang sebagai tempat juga dapat dikelompokkan berdasarkan tingkat kepentingannya, yaitu Lemah Cai: Lemah berarti tanah dan Cai berarti air, filosofi ini biasanya ada di perkampungan yang letak perkampungannya berada di pegunungan. Luhur Handap: konsep ini menunjukan hierarki penempatan suatu lokasi berdasarkan tingkat kepentingan/ fungsinya. Wadah Eusi: mempunyai arti bahwa setiap tempat dalam sebuah perkampungan selalu menjadi wadah yang juga memiliki isi (eusi) yang artinya memiliki kekuatan supranatural (Kustianingrum,dkk., 2013:2). Kata ruang dapat ditempatkan dalam suatu wilayah atau permukiman, tidak hanya dibatasi oleh dinding tertutup (ruang interior), namun ia dapat menjadi "ruang" abstrak yaitu wadah dengan "isi" yang ada di dalamnya berupa kualitas yang terdapat pada sistem kepercayaan.

\section{METODE PENELITIAN}

Penelitian ini bertujuan mengamati kebudayaan yang ada di Kampung Dukuh, terutama Kampung Dukuh Dalam. Menurut Spradley (2007:5) mengambil pernyataan Marvin Haris, bahwa konsep kebudayaan ditampakkan dalam berbagai pola tingkah laku yang dikaitkan dengan kelompok-kelompok masyarakat tertentu, seperti adat atau cara hidup masyarakat. Metode yang digunakan adalah deskriptif dengan pendekatan kualitatif. Menurut Rosali mengutip dari Sukmadinata (2019:69) (Di \& Adat, 2019), bahwa penelitian kualitatif ditujukan untuk mendeskripsikan dan menganalisis fenomena, peristiwa, aktivitas sosial, sikap, kepercayaan, persepsi, pemikiran orang secara individual maupun kelompok. Penelitian ini mengamati suatu kelompok tertentu yaitu Kampung Dukuh. Teknik pengumpulan data dilakukan dengan merekam, wawancara, dokumentasi dan observasi kehidupan masyarakat Kampung Dukuh. Pengumpulan data dilakukan dengan langsung menuju ke lapangan yang berlokasi di Kampung Dukuh Desa Cijambe, Kecamatan Cikelet, Kabupaten Garut. Pengamatan langsung dilapangan yaitu Kampung Dukuh, dilakukan selama dua hari dengan mengambil waktu saat kegiatan ritual

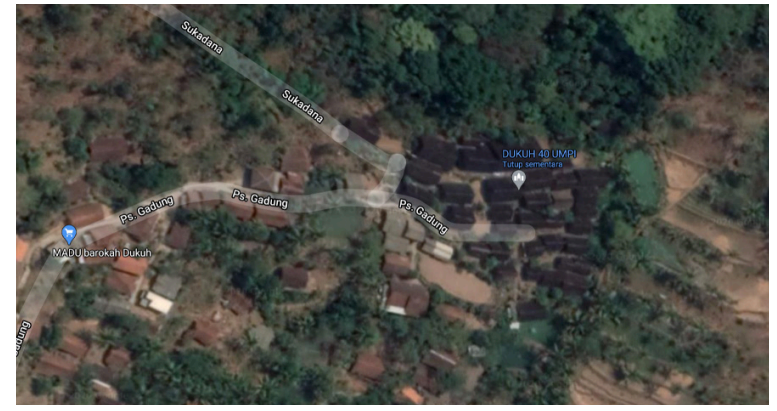

Gambar 1. Letak Geografis Kampung Dukuh (google maps, Agustus 2020)

yang rutin dilakukan oleh masyarakat Kampung Dukuh Dalam, yaitu Jumat dan Sabtu saat adanya kegiatan sholawat/ selawat dan ziarah makam. Hal ini dilakukan agar peneliti dapat mengamati secara objektif, merekam, mendokumentasikan kegiatan ritual adat pada hari Jumat malam yaitu sholawat/selawat dan ziarah Sabtu pagi. Wawancara juga dilakukan agar mendapatkan data secara mendalam. Wawancara dilakukan kepada narasumber yang terpilih, yaitu narasumber utama seperti kuncen (juru kunci) yaitu Mama Uluk, dan lawang (asisten kuncen) yaitu Ma Komsiah. Wawancara dari narasumber utama ini menjadi sangat penting, karena ia merupakan sumber pengetahuan perihal adat istiadat Kampung Dukuh. Narasumber lain juga dibutuhkan untuk mendukung data yaitu wawancara kepada ketua RT, RW dan warga. Pengumpulan data secara literatur dari berbagai sumber serta data di lapangan dan juga dokumentasi selanjutnya di analisis dengan memaparkan secara berurut sampai kepada kesimpulan. Penelitian ini bertujuan memahami budaya Kampung Dukuh dikaitkan dengan ruang aktivitasnya dan memahami makna batas ruang yang mereka ciptakan.

Hasil penelitian ini tentunya akan memperkaya perbendaharaan peneliti juga pembaca dalam memahami kebudayaan Sunda. Penelitian terdahulu dari kampung Sunda lainnya memberi referensi dan perbandingan antara kampung satu dengan kampung Sunda lainnya. Penelitian ini juga dapat menjadi acuan data bagi masyarakat atau pihak yang ingin berkontribusi dalam pengabdian di Kampung Dukuh.

\section{ANALISIS DAN INTEPRETASI DATA}

\section{Kampung Dukuh}

Kampung Adat Dukuh terletak di Desa Cijambe, Kecamatan Cikelet, Kabupaten Garut. Lokasinya berada di lereng Gunung Dukuh. Wilayah kampung ini berada di antara dua aliran sungai, yakni Sungai Cimangke dan Sungai Cipasarangan. Terletak di antara tiga gunung, yakni Gunung Batu Cupak, Gunung Dukuh, dan Gunung Batu. Akses menuju Kampung Dukuh menanjak dengan jalan yang berbatu. Kampung Dukuh merupakan kampung adat Sunda dengan masyarakat yang berbahasa Sunda.

Kawasan Kampung Dukuh seluas $\pm 10 \mathrm{Ha}$, dengan pembagian 1,5 Ha Kawasan perumahan Kampung Dukuh dan 8,5 Ha Taneuh Karomah (Hutan Adat dan Makom Karo- 
mah). Kawasan perumahan Kampung Dukuh dibagi kepada Kampung Dukuh Dalam dan Kampung Dukuh Luar. Tanah pemukiman Kampung Dukuh bukan hak milik pribadi melainkan tanah adat yang diatur secara adat atas sepengetahun dan ijin kuncen (juru kunci). Dari penjelasan berbagai narasumber yaitu salah satunya dari kuncen (juru kunci) Mama Uluk dan juga dari berbagai sumber (Rosyadi, 2015:419), bahwa fungsi lahan di Kampung Dukuh terbagi beberapa bagian yaitu;

1. Tanah karomah, yaitu lahan yang berada bagian atas dari kawasan pemukiman Dukuh Dalam dengan dibatasi oleh pagar. Di area ini terdapat makam karomah yaitu tempat dimakamkannya Syekh Abdul Jalil yang merupakan pendiri kampung Dukuh. Kawasan ini terlarang dan hanya boleh dimasuki pada waktu dan orang tertentu saja.

2. Tanah awisan, atau disebut juga tanah titipan, merupakan wilayah yang diperuntukkan bagi tempat pemukiman warga Dukuh. Penempatan rumah di tanah ini harus atas sepengetahuan dan seijin kuncen. Jika tanah tersebut bukan hak milik dan tidak diperjual belikan, namun untuk fisik rumah boleh diperjual belikan dengan perjanjian kesepakatan pemilik rumah.

3. Tanah garapan, yaitu wilayah yang digunakan sebagai lahan garapan warga, misal dibuat huma, sawah. Tanah garapan oleh warga Dukuh ini digunakan sebagai kebun, kolam ikan dan juga untuk ditanami pohon-pohon besar seperti albasiah dan jati.

4. Tanah tutupan, yaitu kawasan hutan yang tertutup untuk digunakan dan dieksploitasi.

5. Tanah cadangan, yaitu wilayah yang diperuntukkan bagi lahan pemukiman warga.

Hutan Adat ini menjadi sumber kehidupan bagi Kampung Dukuh. Sebagaimana pernyataan Mama Uluk (Uluk, 2020) "Lembok leuweungna, curcor caina, tinantu hurip rahayatna uga ruawat leuweung sarua jeung nyaah $k a$ diri urang pribadi, yu atuh urang wujudkeun leuweung: tutupan, titipan, garapan, larangan sareung cadangan pikeun nyalameutkeun urang balarea"

(Hijau/subur hutannya, air berlimpah ruah, tentunya rakyatnya makmur, pelihara hutannya harus seperti merawat terhadap diri sendiri, mari kita buktikan hutan sebagai amanah: tutupan, titipan, garapan, larangan dan tanah cadangan untuk keselamatan kita bersama.)

Hutan di Tanah Karomah menjadi sumber air bagi Kampung Dukuh, dan untuk beberapa ritual seperti Cebor Empat Puluh, dan mandi sebelum ziarah, airnya harus bersumber langsung dari hutan di tanah tersebut dan didoakan oleh kuncen (juru kunci) atau lawing (asisten kuncen). Menurut Syukur (Syukur \& Qodim, 2017:142), Hutan Larangan tidak boleh diganggu seperti mengambil kayu atau ranting yang telah lapuk, sehingga kelestarian alam (natural conservation), keaneka-ragaman hayati (flora dan fauna) serta tata kelola air (hidrologi) tetap tersedia dan terjaga dengan baik.

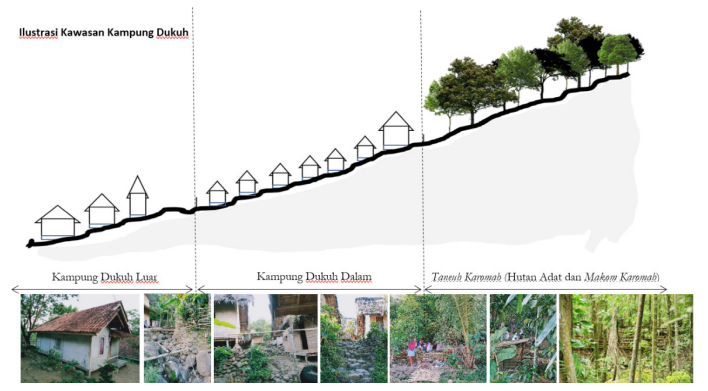

Gambar 2. Ilustrasi/Gambaran Pembagian Kampung Dukuh (Nani, Juli 2020)

Batas antara ketiga zona Tanah karomah -pemukiman Dukuh Dalam - pemukiman Dukuh Luar berupa pagar bambu dan tanaman. Susunan rumah bertingkat mengikuti kontur tanah. Paling atas merupakan Taneuh Karomah, dibawahnya Kampung Dukuh Dalam dan bagian terbawah adalah Kampung Dukuh Luar. Batas dan tata letak yang terbentuk antara Taneuh Karomah (Hutan Adat+Makom Karomah)Kampung Dukuh Dalam - Kampuh Dukuh Luar merupakan batas yang menunjukkan tingkatan kesakralan suatu ruang. Makin keatas semakin sakral dengan adanya ketentuan dan aturan-aturan adat bagi masyarakat Kampung dan juga pengunjung atau peziarah.

Ritual kunjungan atau ziarah ke makam/Makom Karomah dilakukan setiap hari Sabtu. Di Taneuh Karomah ini terdapat makam Syekh Abdul Jalil, yang merupakan karuhun (leluhur) masyarakat Kampung Dukuh dan makam dari keturunan kuncen Kampung Dukuh yang letaknya terpisah dari area pemakaman umum. Selain itu juga terdapat tempat pemakaman umum yang diperuntukkan bagi warga Kampung Dukuh. Di dalam wilayah karomah ini warga tidak diperbolehkan mendirikan bangunan dan lahannya tidak boleh digunakan sebagai lahan garapan (Rosyadi, 2015:419). Aturan yang wajib dipatuhi bagi peziarah untuk memasuki area Tanah Karomah adalah pengunjung bukan/ tidak bekerja sebagai karyawan PNS/ASN (Pegawai Negri Sipil/ Aparatur Sipil Negara). Pengunjung makam yang masuk harus dalam keadaan suci yaitu bagi perempuan tidak sedang haid, sudah mandi besar, berwudhu, menggunakan pakaian bersih polos tanpa menggunakan dalaman, wangi, tanpa alas kaki, dan saat di dalam tidak boleh meludah dan kentut.

Di area Dukuh Dalam, tidak adanya batasan untuk para pengunjung yang ingin masuk ke kawasan ini, hanya saja untuk penghuni yang menetap di daerah Dukuh Dalam harus mematuhi aturan-aturan yang disampaikan oleh kuncen (juru kunci), yang saat ini dijabat oleh Mama Uluk. Penghuni Dukuh Dalam boleh berasal dari daerah di luar Dukuh atau bukan keturunan langsung Dukuh Dalam, namun tetap atas persetujuan kuncen (juru kunci). Aturan yang harus dilaksanakan oleh penduduk kampung Dukuh Dalam adalah tawadhu, sederhana dan harmonis. Di Dukuh Dalam dilarang menggunakan listrik, melak- 


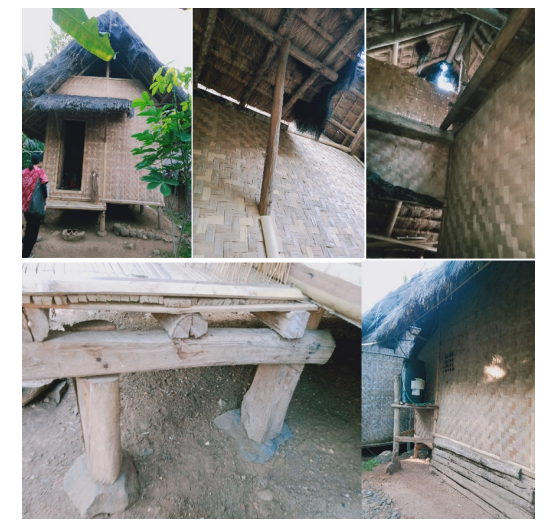

Gambar 3. Rumah Kampung Dukuh Dalam (Nani, Juli 2020)

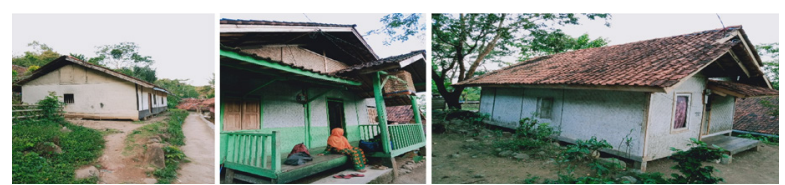

Gambar 4. Perumahan di Dukuh Luar (Nani, Juli 2020)

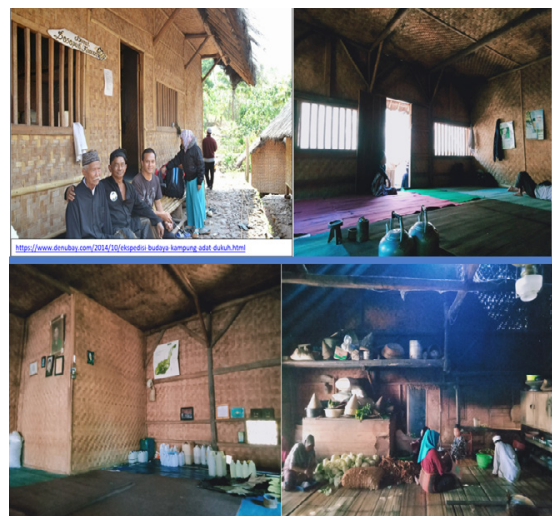

Gambar 5. Bumi Adat di Kampung Dukuh Dalam

(Nani, Juli 2020)

sanakan aturan agama dengan berpedoman kepada Al-Quran dan Hadis. Rumah-rumah tersusun membujur barat ke timur, dengan bentuk rumah dari bambu dan kayu sebagai struktur serta penutup atap dari ijuk. Bentuk rumah yang tipikal sama, namun ukuran tiap-tiap rumah tidaklah sama. Luas rumah disesuaikan dengan penghuni rumah. Dilarang berlebih-lebihan artinya rumah menggunakan bahan alami, sesuai ukuran luas dengan penghuninya dan bahan-bahan rumah yang alami dengan dilarangnya penggunaan tembok, ornamen, kaca dan sebagainya. Jika individu tidak sanggup untuk mengikuti aturan-aturan tersebut maka ia boleh untuk keluar dari Kampung Dukuh Dalam dan tinggal di Kampung Dukuh Luar.

Wilayah Kampung Dukuh Luar memiliki aturan yang lebih longgar dari pada Dukuh Dalam. Kuncen (juru kunci) memberikan kebebasan kepada masyarakat Kampung Dukuh Luar untuk membangun rumah yang berbeda dari kampung Dukuh Dalam serta aturan-aturan lainnya yang tidak berlaku bagi masyarakat Kampung Dukuh Luar. Di
Kampung Dukuh Luar, masyarakat dapat menggunakan listrik, rumah boleh menggunakan papan kayu, genting dan kaca, serta masyarakatnya boleh berdagang.

Tingkatan kepemimpinan tertinggi adalah kuncen (juru kunci), yang saat ini dipegang oleh Mama Uluk. Kedudukan kuncen ini paling dihormati dari pada Kepala Desa, ketua RW ataupun RT. Kuncen (juru kunci) mempunyai lawang (asisten kuncen), yaitu lawang kulon dipegang oleh Mang Eded dan lawang kaler oleh Ang Umuh, dan lawang perempuan yang dipegang oleh Ma Komsiah. Berbagai ritual adat yang dilaksanakan di Kampung Dukuh dipimpin oleh kuncen dan asisten kuncen (lawang) jika kuncen berhalangan hadir.

Upacara rutin yang diadakan masyarakat Kampung Dukuh selain shalawat/selawat, cebor opat puluh dan ziarah antara lain Ngahaturankeun tuang yaitu kegiatan yang dilakukan masyarakat Kampung Dukuh atau pengunjung luar apabila memiliki maksud tertentu seperti kelancaran dalam usaha, perkawinan, jodoh, dengan cara memberikan bahan makanan berupa garam, kelapa, telur, ayam, kambing atau hewan lainnya sesuai dengan kemampuan, Nyanggakeun yaitu kegiatan penyerahan sebagian hasil pertanian kepada kuncen untuk diberkahi dan masyarakat tidak diperbolehkan memakan hasil panennya sebelum melakukan kegiatan ini, Tilo Waktos yaitu pemberian doa oleh kuncen terhadap makanan yang akan dihidangkan untuk merayakan hari besar Islam 1 Syawal, 10 Rayagung, 12 Maulud, 10 Muharam, Manuja yaitu penyerahan bahan makanan sebagai hidangan di hari raya Idul Fitri dan Idul Adha yang diambil dari hasil bumi kepada kuncen untuk diberkati, Maros yaitu menyerahkan sebagian hasil bumi yang dimiliki kepada aparat pemerintahan, seperti lurah dan camat (Rosyadi, 2015:40).

\section{Ruang Adat di Kampung Dukuh Dalam}

Wilayah Kampung Dukuh terdiri dari Kampung Dukuh Dalam dan Kampung Dukuh Luar. Kampung Dukuh Dalam menjadi pusat adat istiadat Kampung Dukuh. Hutan Karomah menjadi bagian Dukuh Dalam dalam pelaksanaan beberapa ritual. Mama Uluk selaku kuncen (juru kunci) juga berperan sebagai pemimpin kampung, dan ia tinggal di Bumi Adat di dalam Kampung Dukuh Dalam. Bumi Adat memiliki bangunan yang lebih besar dari rumah penduduk lainnya. Di Bumi Adat ini, selain sebagai tempat tinggal kuncen, ia juga sebagai tempat kuncen menerima tamu, melakukan ritual adat seperti shalawat/selawat dan ritual lainnya. Di Bumi Adat juga terdapat dapur umum dan masyarakat bergotong royong menyiapkan makanan untuk tamu.

Di Kampung Dukuh Dalam juga terdapat Masjid dan Madrasah dengan posisi yang berdekatan. Panggilan sholat dilakukan dengan membunyikan bedug, dikarenakan adanya larangan pengeras suara. Didepan masjid terdapat kolam untuk berwudhu, dan di bagian samping masjid ter- 


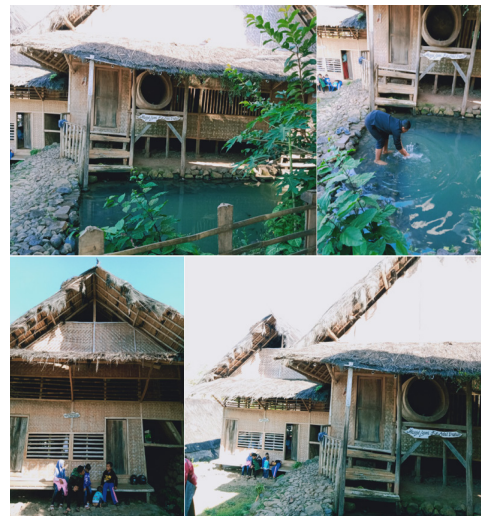

Gambar 6. Masjid dan Madrasah di Kampung Dukuh Dalam (Nani, Juli 2020)

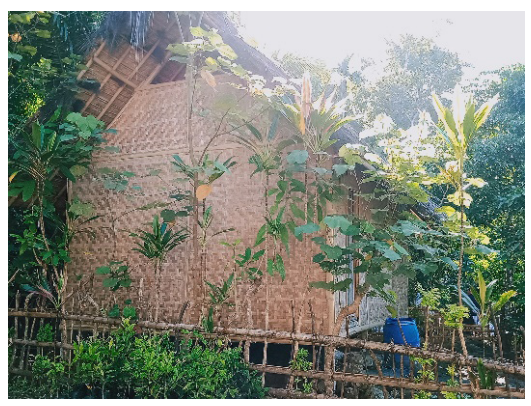

Gambar 7. Rumah Awal di Kampung Dukuh Dalam (Nani, Juli 2020)

dapat jamban. Kegiatan madrasah berupa pengajian setiap ba'da Dhuhur, Ashar, Magrib dan Isya diikuti oleh anakanak dan remaja.

Sejajar dan bersebelahan setelah lapangan di Bumi Adat terdapat rumah awal tempat tinggal dengan tempat tinggal Aki dan Nini Chandra yang diteruskan didiami oleh Syech Abd.Jalil. Rumah tersebut diberi batas pagar dan tidak boleh dimasuki, dan ia berfungsi sebagai tempat untuk munajat.

Selain itu juga terdapat tempat mandi Cebor Opat Puluh yang airnya langsung dari hutan keramat. Tempat mandi ini juga ramai saat akan mandi besar sebelum melakukan ziarah. Air sudah didoakan terlebih dahulu oleh kuncen dan lawang. Ritual mandi dengan air yang sudah didoakan ini dilakukan sebelum akan ziarah ke makam. Ma Komsiah selaku lawang, meletakkan jerigen air yang telah didoakan dan botol-botol kosong di depan rumahnya agar masyarakat bisa mengambil sendiri air sebelum mereka mandi.

Di bawah bangunan Bumi Adat Kampung Dukuh Dalam terdapat Bale Adat dan rumah warga. Jumlah bangunan di pemukiman Kampung Dukuh Dalam di sekitaran 40 bangunan. Menurut Sumardjo, (2003:304) umumnya kampung Sunda yang masih mempertahankan adat istiadat umumnya berjumlah 40 rumah, hal ini dirasa ideal untuk hunian manusia ladang.

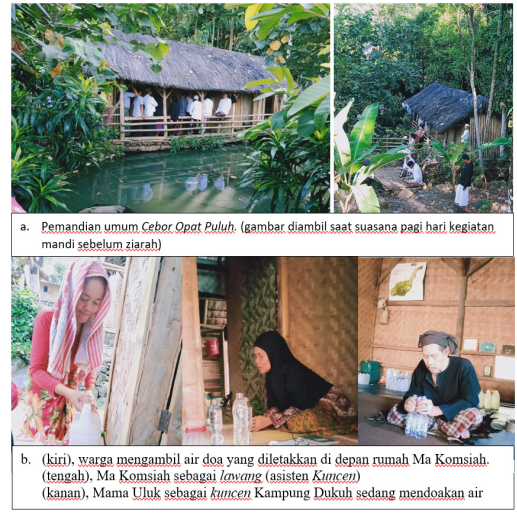

Gambar 8. Ritual mandi dan air doa di Kampung Dukuh Dalam (Nani, Juli 2020)

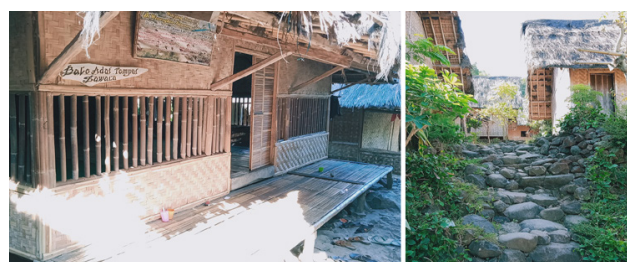

Gambar 9. Bale Adat dan Perumahan di Kampung Dukuh Dalam

(Nani, Juli 2020)

Jumlah penghuni dalam satu rumah tidak dibatasi namun di dalam rumah hanya terdiri dari 1 kepala keluarga, jika ada anak yg sudah berkeluarga maka harus keluar dari rumah. Ukuran rumah tidak sama setiap rumahnya, dikarenakan menyesuaikan kontur dan juga penghuni rumah, seperti contoh rumah Ma Komsiah yang hanya terdapat 1 kamar dan ukuran rumahnya tidak terlalu besar dibandingkan dengan rumah lainnya, dikarenakan Ma Komsiah hanya tinggal sendirian di rumah tersebut. Pimpinan adat secara turun temurun memberi aturan perihal bentuk bangunan di Kampung Dukuh Dalam, yaitu bentuk bangunan panggung (lantai tidak langsung bersentuhan dengan tanah) persegi panjang dengan bagian atas (penutup atap) hitam yaitu berbahan ijuk, struktur material bangunan berbahan kayu dan bambu, dinding berbahan anyaman bambu, pintu berbahan kayu, penutup lantai dari palupuh (bambu yang dipipihkan) (lih. Gambar 3.). Tiang-tiang kayu sebagai struktur utama bangunan diletakkan diatas batu sebagai tapak, agar kayu tidak langsung bersentukan dengan tanah. Bahan kayu tidak di finishing, dan berupa papasan artinya kebutuhan kayu yang digunakan dihitung dengan cermat sehingga pas saat digunakan, yang bermakna agar tidak berlebih-lebihan. Posisi/arah pintu utama bisa dimana saja kecuali tidak boleh menghadap kaler (utara).

Larangan posisi pintu mengahadap kaler dikarenakan arah tersebut merupakan tempat makam keramat/makam leluhur, sehingga tidak sopan jika masuk kedalam rumah namun membelakangi makam keramat. Bentuk rumah harus mencerminkan kesederhanaan, tidak berlebih-leb- 
ihan dan harmonis bersama. Bentuk persegi empat pada semua bangunan juga mencerminkan 4 mazhab fiqih yaitu Hanafi, Maliki, Syafii, dan Hambali. Hal ini juga berkaitan dengan keyakinan yang dianut oleh masyarakat Kampung Dukuh. Masyarakat Kampung Dukuh menganut agama Islam dengan mazhab Syafii. Masyarakat Kampung Dukuh terutama Dukuh Dalam sangat taat menjalankan ajaran agama Islam, menjalankan yang wajib juga sunnah. Ajaran yang disampaikan berdasarkan Al-Quran dan Hadits, dan nasehat adalah tentang akhlak yang diterapkan dalam kehidupan sehari-hari baik dalam lingkungan keluarga maupun dalanm bermasyarakat. Konsep yang ditanamkan tersebut yaitu tawadhu berarti menerima dan bersyukur dengan apa yang ada, sederhana tidak bermewah-mewahan karena kemewahan akan menimbulkan keserakahan dan malapetaka, harmonis yang berarti masyarakat dukuh harus bergotong royong, dan juga menjaga alam sebagai sumber penghidupan.

Batas Ruang Dalam dan Luar di Kampung Dukuh ini juga terlihat dengan aturan dan larangan adat kepada masyarakat Kampung Adat Dalam (wawancara dan (Di \& Adat, 2019:73), beberapa diantaranya yaitu;

1. Tidak berdagang di lingkungan Dukuh Dalam, dimaksudkan agar tidak terjadinya kecemburuan sosial dan iri hati. Hal ini kembali kepada konsep yang ditanamkan kepada warga agar hidup harmonis sesame masyarakat.

2. Tidak menggunakan listrik dan barang elektronik. Hal ini agar menjaga kekhusuy an dan tidak mengurangi tingkat ketakwaan dalam menjalankan ibadah.

3. Tidak bekerja sebagai Pegawai Negeri Sipil (PNS). Hal ini berkaitan dengan sejarah tentang Syekh Abdul Jalil yang mengundurkan diri dari jabatannya sebagai pemuka agama di kerajaan Sumedang. Syekh Abdul Jalil mengundurkan diri karena bupati Sumedang pada saat itu pangeran Rangga Gempol II mengkhianati janjinya terhadap Syekh Abdul Jalil dengan melanggar syara yaitu melakukan pembunuhan terhadap utusan yang berasal dari pemerintahan kerajaan Banten.

Pelanggar aturan dan larangan adat mendapat sangsi dengan berpuasa selama 40 hari, jika tetap melanggar maka mereka percaya akan mendapat musibah.

Pembagian Dalam dan Luar melalui aturan, larangan dan ritual yang hanya dilakukan di Kampung Dukuh Dalam menjadikan Dukuh Dalam memiliki ruang ritual tersendiri. Batasan ruang memberikan nuansa dan suasana sakral. Larang, aturan adat dan ritual tersebut bertujuan menjaga ketaatan, kekhusyu-an, dan keyakinan dalam beribadah. Hal ini juga berkaitan dengan "wadah" sebagai tempat serta "isi" didalamnya. Menurut Sumardjo (Sumardjo, 2003:259), pola pikir masyarakat Sunda tradisional adalah adanya kategori "luar" dan "dalam", keberadaannya yang saling bertentangan tetapi menyatu dalam totalitas ke-

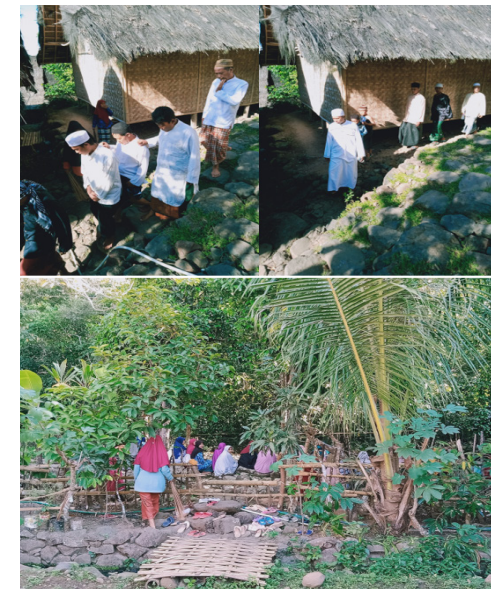

Gambar 10. Warga yang akan melakukan ritual ziarah di Kampung Dukuh Dalam

(Nani, Juli 2020)

beradaan. Selanjutnya, hubungan "dalam" tersebut adalah hubungan wadah dan isi, serta hubungan kepentingan bersama. Pada kasus Kampung Dukuh adalah pemisahan antara Kampung Dukuh Dalam Luar, dibatasi untuk dipisah namun saling berdampingan. Masyarakat yang berada di Kampung Dukuh Luar mematuhi kuncen dan menjalankan sebagian aturan, sedangkan mayarakat yang berada di Kampung Dukuh Dalam mutlak mematuhi dan mentaati berbagai aturan dan larangan adat yang bertujuan menjaga ajaran agama Islam.

Manusia sebagai isi merupakan manusia yang tidak sembarangan betapapun tinggi mutunya, maka ia tidak akan diakui sebagai "orang dalam", karena wadah menolak isinya. Manusia isi "asing" tersebut adalah pihak "luar". Wadah-wadah harus mengenal identitas manusia isi, kalau identitas itu diterima, maka akan terbentuklah kesatuan "dalam". Identitas sebagai "dia orang kita" dan "dia bukan orang kita" menjadi syarat terbentuknya lingkungan "dalam" dan "luar". Inilah pola pikiran tradisional itu. (Sumardjo, 2003:262). Pernyataan tersebut tercermin dalam kehidupan bermasyarakat di Kampung Dukuh Dalam. Jika individu tidak sanggup mengikuti aturan adat maka kuncen mempersilahkan ia untuk keluar dari Kampung Dukuh Dalam, jika orang luar ingin masuk menjadi warga Dukuh Dalam maka ia harus taat menjalankan aturan Kampung Dukuh Dalam.

Suasanan sakral ibadah di kampung Dukuh Dalam ini terasa karena tidak adanya keributan, perselisihan, masyarakat harmonis, ramah, kesatuan rasa dan tujuan sama. Pengunjung luar Dukuh yang datang dan ikut serta beribadah di lingkungan Dukuh Dalam disambut namun tetap mengikuti aturan dan ketentuan adat.

Kegiatan jiarah salah satunya adalah kegiatan yang juga diikuti oleh pengunjung dari luar daerah, namun tetap dengan mematuhi aturan adat yang telah di paparkan sebelumnya. Aturan-aturan adat tersebutlah yang menjaga ruang 
menjadi sakral dan khusyu dalam beribadah, baik hubungan ibadah habluminallah dan habluminannas.

\section{SIMPULAN}

Batas dan pemisahan Kampung Dukuh yaitu Kampung Dukung Dalam dan Kampung Dukuh Luar berkaitan dengan wadah dan isi. Kampung Dukuh Dalam menempatkan diri sebagai wadah dengan mengatur isi di dalamnya. Melalui kuncen sebagai pemimpin Kampung Dukuh, memiliki isi berupa ajaran-ajaran, nilai-nilai dan warisan pengetahuan turun temurun bertugas menyampaikan kepada para pengikutnya yaitu warganya. Kuncen mengenal betul orang yang layak menjadi "orang dalam", hal ini bertujuan menjaga wadah Kampung Dukuh Dalam tetap terjaga kualitas isinya, yaitu kesakralan dan kekhusyu-an dalam menjalankan ibadah. Kuncen berperan membuat keputusan dalam membentuk kehidupan spiritual kampungnya melalui batas ruang adat, fisik ruang dan mengatur kehidupan bermasyarakat di dalamnya. Keputusan dan aturan adat tersebut berlandaskan ajaran agama Islam yang berpedoman pada Al-Quran dan Hadits. Fisik ruang adat tidak tersentuh oleh kemewahan duniawi masa kini seperti tidak boleh adanya listrik dan barang-barang elektronik, serta bentuk bangunan lingkungan yang alami dan sederhana. Ibadah wajib harus dilaksanakan dan ibadah sunnah juga selalu dikerjakan. Kesakralan ini menjaga masyarakatnya menjadi manusia yang selalu bersyukur, taat, rukun, harmonis, tidak bermewah-mewahan dan bergotong royong.

\section{UCAPAN TERIMAKASIH / PENGHARGAAN}

Ucapan terima kasih disampaikan kepada Prof. Dr. Reiza D. Dienaputra selaku Promotor. Terima kasih juga diucapkan kepada Dr. Susi Machdalena, Ph.D. dan Dr. N. Kartika sebagai Co-Promotor di Program Studi Sastra, Fakultas Ilmu Budaya, Universitas Padjadjaran yang telah membantu dalam proses penelitian ini.

\section{DAFTAR RUJUKAN}

\section{Artikel Jurnal}

Kustianingrum, D., Sonjaya, O., \& Ginanjar, Y. (2013). Kajian Pola Penataan Massa Dan Tipologi Bentuk Bangunan Kampung Adat Dukuh Di Garut, Jawa Barat. Jurnal Reka Karsa, 1(3), 1-13.

Rosali, E. S., Mainaki, R., (2019). Nilai-Nilai Kebudayaan Di Kampung Adat Dukuh Sebagai Bentuk Kearifan Lokal Hidup Selaras Dengan Lingkungan. Nilai-Nilai Kebudayaan Di Kampung Adat Dukuh Sebagai Bentuk Kearifan Lokal Hidup Selaras Dengan Lingkungan, 19(1), 67-75. https://doi.org/10.17509/gea.v19i1.15536

Rosyadi. (2015). Dalam Kajian Kearifan Lokal ( Studi Ka- sus Pada Masyarakat Adat Kampung Dukuh ). Patanjala, 7(3), 415-430.

Syukur, A., \& Qodim, H. (2017). Islam, Tradisi Lokal, dan Konservasi Alam: Studi Kasus di Kampung Dukuh Kabupaten Garut. Kalam, 10(1), 141. https://doi.org/10.24042/ klm.v10i1.339

\section{Buku}

Permana, R. C. E. (2006). Tata Ruang Masyarakat Baduy. Jakarta: Wedatama Widya Sastra.

Rosidi, A. (1984). Ciri-Ciri Manusia dan Kebudayaan Sunda. In E. S. Ekadjati (Ed.), Masyarakat Sunda dan Kebudayaannya (pp. 125-163). Jakarta: Girimukti Pasaka.

Suhamihardja, A. S. (1984). Agama, Kepercayaan dan Sistem Pengetahuan. In E. S. Ekadjati (Ed.), Masyarakat Sunda dan Kebudayaanya (pp. 277-304). Jakarta: Girimukti Pusaka.

Sumardjo, J. (2003). Simbol-simbol Artefak Budaya Sunda. Tafsir-tafsir Pantun Sunda. Bandung: Kelir.

\section{Daftar Nara Sumber/Informan}

Iip, (Juli, 2020). Pemuda Kampung Dukuh, diwawancara tanggal 24-25 Juli 2020 di rumahnya Kampung Dukuh Luar.

Ma Komsiah, (Juli, 2020). Lawang (Asisten kuncen), diwawancara tanggal 25 Juli 2020 di rumahnya Kampung Dukuh Dalam.

Ma Jiyoh, (Juli, 2020). Warga Kampung Dukuh, diwawancara tanggal 24 Juli 2020 di rumah Iip Kampung Dukuh Luar.

Mama Uluk, (Juli, 2020). Kuncen Kampung Dukuh, diwawancara tanggal 25 Juli 2020 di Bumi Adat Kampung Dukuh Dalam

Ocid, (Juli, 2020). Ketua RT Kampung Dukuh, diwawancara tanggal 25 Juli 2020 di rumah Iip Kampung Dukuh Luar. 